\title{
ARTIGO N9
}

DO ABANDONO A UM NOVO VALOR NO PROJETO E NA APROPRIAÇÃO DA PAISAGEM

FROM ABANDON TO A NEW VALUE IN THE PROJECT AND

LANDSCAPE APPROPRIATION

RAMÓN STOCK BONZI 


\title{
DO ABANDONO A UM NOVO VALOR NO PROJETO E NA APROPRIAÇÃO DA PAISAGEM
}

\author{
RAMÓN STOCK BONZI* \\ *Professor de jardinagem, especialista em meio ambiente e sociedade pela Fundação Escola de \\ Sociologia e Política de São Paulo, aluno do curso de pós-graduação Arquitetura da Paisagem \\ (Senac) e mestrando na FAUUSP na área de concentração Paisagem e Ambiente. \\ e-mail: rsb@usp.br
}

\begin{abstract}
RESUMO
Apesar de todos os problemas que as áreas abandonadas acarretam para o meio ambiente urbano, alguns dos projetos paisagísticos mais notáveis das últimas décadas floresceram justamente nesses locais. O presente artigo defende a idéia de que as estruturas abandonadas pelo homem podem constituir-se em importante dimensão do projeto de paisagem. São apresentados recentes esforços teóricos que tratam da interface entre paisagem e áreas abandonadas para, logo em seguida, procederem-se estudos de caso. A requalificação de áreas abandonadas pode resultar em benefícios sociais, econômicos e ambientais, mas para isso é necessário enfrentar questões teóricas e práticas recém-formuladas.
\end{abstract}

Palavras-chave: Brownfield - Área degradada - Paisagem pós-industrial - Landscape Urbanism - Terceira Paisagem - Requalificação urbana.

\section{FROM ABANDON TO A NEW VALUE IN THE PROJECT AND LANDSCAPE APPROPRIATION}

\begin{abstract}
In spite of all problems caused to urban environment by derelict areas, some of the most notable landscape projects flourished precisely at such places during the last decades. This article support the idea that abandoned structures may form an important contribution to landscape project. It is presented recent theoretical efforts that focus the interface between the landscape and abandoned areas and right after are presented study of cases. The requalification of abandoned areas may result in social, economic and
\end{abstract}


environmental benefits, but it is necessary to confront theoretic and practical questions recently formulated.

Keywords: Brownfield; Derelict Area; Post-Industrial Landscape; Landscape Urbanism; Third Landscape; Urban Renewal.

\section{INTRODUÇÃO}

Apesar de o adensamento populacional ser um dos maiores desafios do planejamento urbano deste novo milênio estudos da ONU apontam que até 2025 pelo menos $60 \%$ da população mundial será urbana), cidades em todo o planeta observam o surgimento de áreas abandonadas, praticamente inabitadas, muitas vezes em áreas centrais de seus territórios.

Os processos que têm esvaziado vastas áreas urbanas são dos mais variados: fim de ciclos econômicos, mudanças de legislação, substituição de matrizes de transporte, obsolescência de infraestrutura, desmilitarização, especulação imobiliária, contaminação do solo, urbanização inadequada, esgotamento da exploração de recursos naturais, assoreamento de portos e término da vida útil de edificações.

Nos países desenvolvidos - e também em cidades da periferia do capitalismo global, como São Paulo - tal fenômeno tem sido majoritariamente atribuído à transição da economia industrial para a economia baseada em serviços. As consequências do fenômeno são perversas: além da degradação da paisagem, o tecido urbano abandonado torna-se reduto de criminalidade que afugenta novos moradores e empresas e incentiva o êxodo de antigos residentes. Estes, além de ter que desistir do lugar em que vivem, amargam a desvalorização financeira de suas propriedades.

No entanto, apesar de todos os problemas que as áreas abandonadas acarretam para o ambiente urbano, alguns dos projetos paisagísticos mais notáveis das últimas décadas floresceram justamente aí. O High Line, por exemplo, é um parque nova-iorquino construído sobre uma linha ferroviária desativada nos anos 80. Em São Paulo, a paisagista Rosa Kliass manteve parte das ruínas do inacabado Complexo Penitenciário Carandiru II no Parque da Juventude e a praça Victor Civita foi erigida em terreno do antigo incinerador de Pinheiros. E o Landschaftspark Duisburg-Nord é um parque alemão estruturado em área que já abrigou a siderúrgica Thyssen. 
Em comum, além de terem sido desenvolvidos para áreas que estavam abandonadas, esses projetos recusaram-se a renegar o passado do sítio. Alavancados pelo antigo, propuseram o novo, estabelecendo um diálogo permanente entre presente e passado, entre natureza e sociedade. Também foram intervenções que fomentaram o desenvolvimento de seu entorno, tomando partido de estruturas construídas preexistentes e da vegetação que crescia espontaneamente.

No entanto, as lições ensinadas por esses espaços parecem ainda não terem sido devidamente decodificadas. O presente artigo é esforço nesse sentido.

\section{PLANETA MARROM: DESENCANTO E OPORTUNIDADE}

Segundo McKeeham (2000), nos EUA existem cerca de 600 mil brownfields. Este termo se refere a "empreendimentos que um dia foram desativados, sofreram a ação do tempo, e com a consequente degradação natural transformaram-se em zonas mortas" (VASQUES, 2006, p. 01). Já para o U.S. Department of Housing and Urban Development são 425 mil brownfields que totalizam $20.234 \mathrm{~km}^{2}$ de áreas abandonadas, o equivalente à somada das extensões territoriais das 60 maiores cidades norte-americanas. Em outros termos: mais que 13 cidades de São Paulo.

A Alemanha, segundo Vasques (Idem, p. 02), somaria $1280 \mathrm{~km}^{2}$ de brownfields, enquanto que a Bélgica estaria na faixa de $90 \mathrm{~km}^{2}$ e os Países Baixos com algo entre 90 e $110 \mathrm{~km}^{2}$.

No Brasil, não há dados oficiais ou estimativas sobre a dimensão do problema. No entanto, a desindustrialização de algumas cidades, notadamente a capital de São Paulo, já se faz notar claramente na paisagem urbana. llustrando esse fenômeno temos os inúmeros galpões abandonados, fábricas desativadas e estruturas ferroviárias obsoletas que vêm transformando vastas extensões dos bairros Brás, Barra Funda e Mooca em lugaresfantasma caracterizados por paisagens desoladas e cenários marcados pelo medo.

Conforme explicam Lombardo, Volpe e Vasques "a relação de uma comunidade com uma indústria em funcionamento é diferente da relação que se estabelece quando a mesma encontra-se abandonada. (...) Quando uma indústria fecha (...) a comunidade deixa de receber os benefícios. Nestas condições, aquele espaço antes produtivo torna-se espaço de medo, de rejeição, de marginalidade, convertendo-se em uma pai- 
sagem urbana cujos elementos a população não deseja ver pela frente". (2010, p.07). Outro efeito, segundo Vasques (2006, p. 03) é que brownfields isolados fragmentam o tecido urbano. Solà-Morales vai mais além, definindo que a percepção comum sobre áreas abandonadas estabelece que estas são a 'não-cidade':

São lugares aparentemente esquecidos aonde parece predominar a memória do passado sobre a do presente. (...) De um ponto de vista econômico, áreas industriais, estações ferroviárias, portos, zonas residenciais inseguras e áreas contaminadas se converteram em áreas das quais, pode-se dizer, a cidade não se encontra ali. (2009, p.127)

Na cidade vista como mercadoria, "a sociedade capitalista precisa, por necessidade, criar uma paisagem física - uma massa de recursos físicos construídos pelo homem à sua própria imagem, apropriada, em linhas gerais, às finalidades da produção e do consumo" (HARVEY, 1982, p. 06). O que foi abandonado é lixo, refugo e problema. A lógica da cidade-mercadoria determina que a estrutura abandonada é algo que deve sumir da vista e ser varrida do mapa. Quando muito, reciclada pelos miseráveis. Mas na cidade vista como sonho, projeto que não sem alguma dificuldade foge à lógica econômica, o que foi abandonado é convite à reinvenção.

Em termos práticos, áreas abandonadas constituem-se problemas porque além de estabelecer uma relação conflituosa com os moradores do entorno, possuem muitas vezes o solo contaminado, abrigam edificações gigantescas de onerosa e difícil demolição, fragmentam o tecido urbano e acumulam impostos atrasados. Enfim, constituem um conjunto de fatores que mesmo desvalorizando financeiramente o lote afugenta possíveis novos proprietários, tornando seu redesenvolvimento praticamente impossível. Sua reabilitação necessita de forte intervenção do Estado, como é o caso das polêmicas Operações Urbanas que proliferam na capital paulista.

Mas em termos igualmente práticos, áreas abandonadas revelam-se como oportunidade estratégica para a ampliação da quantidade de áreas verdes urbanas significativas, já que seus lotes possuem tamanhos generosos. Ademais, muitas dessas áreas abandonadas são servidas por sistemas de infraestrutura, localizam-se nas proximidades do centro da cidade e são de fácil acesso por transporte coletivo.

A combinação de problemas sociais, degradação ambiental e ausência de interessados na compra revela-se uma brecha na qual a contenda pelo espaço urbano, em que 
o pêndulo que determina o uso do solo move-se invariavelmente em direção ao preço da terra, pode excepcionalmente deslocar-se rumo à função social do solo urbano, conspirando a favor da criação de áreas verdes e espaços de lazer públicos, idealmente consorciados com equipamentos culturais e habitações de interesse social.

Ligados a atividades-chave responsáveis pelo desenvolvimento de nossas cidades, esses locais abandonados podem reconfigurar-se ainda como patrimônio histórico e/ ou cultural. No entanto, uma vistoria nos parques de São Paulo revela que embora muitos deles tenham sido construídos em áreas abandonadas, a menção ao uso pregresso do espaço praticamente inexiste como uma dimensão do projeto de paisagem.

Os lagos dos Parques Ibirapuera e Cidade Toronto estão sobre antigas cavas de mineração, o Parque Ecológico do Tietê sobre um local que já foi dedicado às atividades de escavação de areia e de aterro sanitário, o Parque Villa-Lobos, em sua porção oeste ergueu-se sobre um depósito de lixo da CEAGESP, ao leste sobre material dragado do Rio Pinheiros, e ao centro, sobre um depósito de entulho da construção civil ${ }^{1}$. O Parque Raposo Tavares está sobre antigo depósito de lixo e o Parque da Juventude sobre o Complexo Penitenciário do Carandiru. No entanto apenas este último incorpora o uso pregresso do espaço como partido de projeto.

Tal quadro é de difícil compreensão já que a preservação e a incorporação de parte das estruturas construídas trazem inúmeras vantagens. Para Sòla-Morales esta seria o procedimento padrão de quem intervém na cidade, o operativo da arquitetura:

Pertence à essência da arquitetura sua condição de instrumento de organização, de racionalização e de eficácia produtiva capaz de transformar o selvagem em cultivado, o baldio em produtivo, o vazio em edificado. Deste modo, quando arquitetura e desenho urbano projetam seu desejo frente a um espaço abandonado, um terrain vague, parece que não podem fazer outra coisa que não seja transformações radicais, (...) pretendendo a todo custo desfazer-se da magia não contaminada do obsoleto no realismo da eficácia (2009, p. 130).

Seja como for, a peculiaridade das intervenções em áreas abandonadas também tem se desdobrado em novas proposições teóricas no estudo da paisagem: "hós, arquitetos paisagistas, não alteramos as áreas industriais abandonadas. Ao invés disso, essas áreas estão mudando o nosso jeito de pensar e a filosofia de nossa profissão" (LATZ, 2003, p. 122).

\footnotetext{
$1<$ http://www.ambiente.sp.gov.br/parquevillalobos/historico.php>. Acessado em 14 de setembro de 2013.
} 


\section{PAISAGEM COMO URBANIZAÇÃO}

No mesmo sentido, Reed (2005) reconhece a influência da obsolescência produtiva na conformação da cidade e no próprio corpo teórico da arquitetura e urbanismo:

O ritmo acelerado em que as cidades estão refazendo-se em vastas extensões de terra está mudando a disciplina da arquitetura da paisagem e desenho urbano. O papel dos espaços abertos na redefinição da cidade moderna tem levado ao desenvolvimento da ideia da paisagem como urbanização (p. 30)

Surgido em meados dos anos 90, o Landscape Urbanism defende que a paisagem, e não mais a arquitetura, deve ser a base para o desenho urbano. Charles Waldheim, professor e chefe de departamento em Harvard, e James Corner, professor e chefe de departamento na Universidade de Pennsylvania (além de ser mundialmente conhecido por seu projeto do High Line Park, em Nova York) - entendem que o desenho urbano não tem conseguido lidar com as mudanças na cidade, sobretudo com as questões ambientais e as relativas à desindustrialização.

Corner argumenta que enquanto a arquitetura se concentra nas superfícies verticais, são as superfícies horizontais aquelas que permitem abordar o espaço urbano em suas várias escalas, "da calçada à rua e até a totalidade da matriz das infraestruturas urbanas". Essa abordagem valoriza a continuidade das superfícies, se esforça em fundir paisagem e espaço construído, entendendo-a como infraestrutura urbana. E "ao contrário da arquitetura, que consome o potencial do lugar em nome do projeto, a infraestrutura urbana deve semear possibilidades para o futuro, fundindo o incerto e o prometido" (2006, p. 30-31).

Segundo Waldheim (2006, p.39), áreas construídas de vastas dimensões (tais como aeroportos, zonas industriais e de logística e instalações para o tratamento de água) devem ser encaradas como uma paisagem infraestrutural (infrastructural landscape). Segundo ele, embora projetos de Olmsted como o Back Bay Fens ${ }^{2}$ possam ser considerados paisagens com funções infraestruturais, o Landscape Urbanism diverge

\footnotetext{
2 Datado do último quartel do século XIX, o Back Bay Fens teve por objetivo combater enchentes e a poluição das várzeas . Como relata SPIRN (1995, p. 163 ), Olmsted recusava o rótulo de parque e considerava que o uso como espaço de lazer era um benefício incidental.
} 
dessa tradição por entender que nesses projetos houve a camuflagem dos sistemas ecológicos por uma concepção pastoral de natureza. Segundo o autor,

\begin{abstract}
as práticas contemporâneas de Landscape Urbanism recomendam o uso dos sistemas de infraestruturas e as paisagens públicas que elas produzem como mecanismos de ordenação urbana, que modelam e alteram a organização dos assentamentos urbanos e sua inevitável indeterminação quanto a seu futuro econômico, político e social (WALDHEIM, 2006, p. 39. )
\end{abstract}

A paisagem se transforma assim em um análogo aos processos contemporâneos de urbanização, metamorfoseando-se em suporte que responde às mudanças temporais, transformações, adaptações e sucessão (p.39), um urbanismo pós-moderno articulado em camadas, não hierárquico, flexível e estratégico que constrói um campo horizontal de infraestrutura que acomoda todo tipo de atividade ao longo do tempo. (p.41).

Na mesma linha, Hung (2011) entende que a integração dos sistemas de infraestruturas com a estrutura da paisagem requer um novo paradigma, mais alinhado como o funcionamento dos sistemas ecológicos naturais. Frente à rapidez de sua obsolescência, aconselha que a infraestrutura seja projetada como flexível, adaptável, descentralizada e multifuncional.

Sob este paradigma, as infraestruturas têm potencial para tornarem-se infraestruturas paisagísticas (landscape infrastructure) "catalisadoras da revitalização urbana, na medida em que aumentam a quantidade de áreas abertas, criam habitats, renovam os laços comunitários e transformam mazelas urbanas em destinos urbanos" (p. 17).

\title{
A NATUREZA DAS ÁREAS ABANDONADAS
}

Da observação de que o espraiamento das atividades humanas sobre o globo terrestre produz espaços intersticiais que não são efetivamente desenvolvidos pelo homem surge o conceito de Terceira Paisagem. Proposto por Gilles Clément, paisagista do Parque André Citroën e professor da Escola Superior de Paisagem de Versalhes, a Terceira Paisagem "inclui restos de território, rural e urbano, e zonas não cultivadas: bordas de estradas e campos, de áreas industriais e reservas naturais" (CLÉMENT, 2008, p. 21). 
A denominação Terceira Paisagem pressupõe a existência de outras duas paisagens. Embora Clément não as defina explicitamente - nem mesmo em seu "Manifesto da Terceira Paisagem" - tudo leva a crer que a Segunda e a Primeira Paisagem dizem respeito, respectivamente, àquelas exploradas ou não pelo homem.

As áreas abandonadas de que tratamos no presente artigo são espaços da Terceira Paisagem por excelência: "incluídos nesta categoria estão áreas urbanas ou rurais deixadas para trás (abandonadas), espaços de transição, terras negligenciadas (terrenos baldios) (...), mas também beiras de estrada, leitos fluviais, taludes de estradas de ferro, etc.". Segundo o autor, "o abandonado (Le délaissé) é o resultado do abandono de um terreno explorado anteriormente. Sua origem é múltipla: agrícola, industrial, urbana, turística, etc." (2004, p.06).

Cléments observa uma série de atributos típicos dessas áreas. E constata que suas potencialidades são ignoradas pelo senso-comum dos que intervém na paisagem:

O fato de que a IFLA (Federação Internacional de Arquitetos Paisagistas) classifica áreas abandonadas como paisagens sob perigo é um sinal realmente revelador. A reapropriação da terra pela natureza é interpretada como decadência, quando na verdade é exatamente o oposto. Este é um estereótipo que permanece, a ideia de que o homem nunca deve abandonar a terra que ele domesticou. Tudo o que o homem abandona ao tempo dá à paisagem uma chance de ser simultaneamente marcada pela sua presença e por sua libertação (2008, p. 21).

O autor lembra que uma vez que um terreno é abandonado, instalam-se rapidamente processos de sucessão ecológica, isto é, diferentes comunidades vegetais povoam a área em sequência mais ou menos previsível, indo da colonização por espécies pioneiras como liquens e gramíneas, passando por arbustos até árvores, chegando a uma comunidade clímax com biodiversidade compatível com o ambiente.

Além de mudar de forma devido à dinâmica natural da sucessão florestal, a Terceira Paisagem varia sua forma em virtude das relações que estabelece com o entorno antropizado. Se este for dominado por práticas contaminantes, ocorrerá perda de diversidade. No entanto, pressão moderada oriunda de um entorno sem práticas contaminantes manterá uma diversidade equilibrada na área abandonada e esta influirá positivamente no entorno. E por fim, "a Terceira Paisagem muda de forma e de proposta por meio do jogo de mercado, que é um jogo político” (2007, p.36). 
Diante disso, Gilles Clément propõe que os espaços abandonados sejam vistos como territórios de refúgio para biodiversidade: "ver a Terceira Paisagem como uma necessidade biológica que altera o futuro de seres vivos modifica a nossa interpretação do território, atribuindo valor a lugares que são normalmente negligenciados" (2008, p. 25). Do ponto de vista social, os espaços abandonados são espaços de natureza, de ócio, improdutivos e sagrados (2007, p.53) a que convém "estabelecer critérios positivos, fixar os limites precisos, definir os usos e estabelecer seu estatuto jurídico". Culturalmente, os espaços da Terceira Paisagem são compartilhados pela consciência coletiva e fazem "referência ao território organizado por oposição a ele" (p. 57).

\section{ESTUDOS DE CASO}

\section{Landschaftspark Duisburg-Nord}

O Landschaftspark Duisburg-Nord é um parque alemão projetado por Peter Latz em área que já abrigou a siderúrgica Thyssen, desativada em 1985. O parque faz parte de um esforço conjunto entre municipalidades da região do Emscher e o governo federal alemão para remodelar uma zona industrial que abriga população de cinco milhões de pessoas.
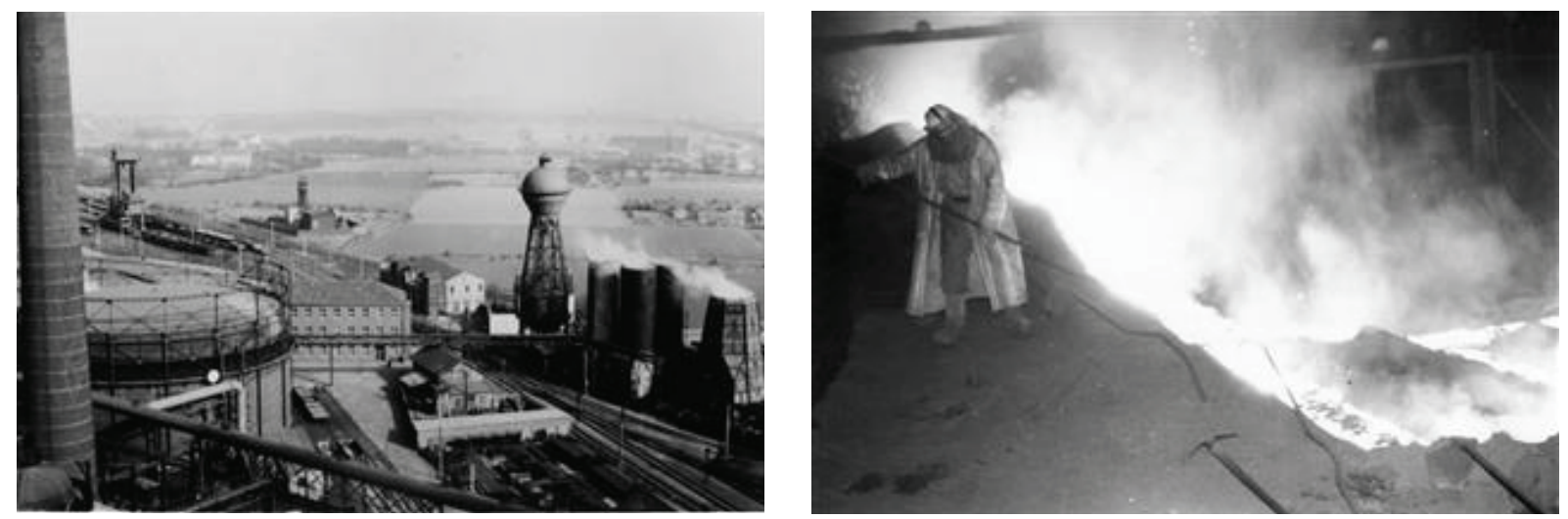

Figuras 1 e 2: Thyssen Stee/works a pleno vapor. Créditos: 1956(c) Jürgen Dreide (esquerda) e 1961(c) Heinz Pelschinski (direita).

Em 1990, uma competição internacional foi lançada para receber propostas de revitalização do terreno da antiga siderúrgica, uma área de 200 hectares. Como relata Weilacher (2008), a comissão julgadora liderada pela arquiteta paisagista Donata Valentien declarou o escritório de Peter Latz vencedor, mas não sem antes manifestar profunda decepção quanto à capacidade dos outros proponentes de respeitar o passado industrial recente e tomar partido das instalações existentes: 
As ideias permaneceram essencialmente aleatórias, e poderiam muito bem ter sido propostas para outros locais, "normais" (...) As ideias desenvolvidas foram surpreendentemente convencionais (..) derivadas de ideias clássicas do paisagismo inglês ou francês. Alinhavam-se com a cultura do esquecimento (...) construí-las significaria que a história e a natureza do lugar teria que ser mais ou menos completamente erradicada. $E$ isso não pode ser encoberto pelo fato de que estruturas siderúrgicas estariam em todos os lugares, como um objeto alienado, incompreensível (apud WEILECHER, 2008, p. 107).

A proposta de Latz foi dar novos usos para as instalações da siderúrgica. O gasômetro foi transformado em torre de mergulho, a sala de fundição em cinema ao ar livre e as laterais de prédios e dutos em paredes para a prática de alpinismo. Entre muitas outras intervenções paisagísticas, destaca-se a Piazza Metallica, praça delimitada por gigantescas estruturas industriais e constituída por 49 placas de aço de 2,2 $\times 2$, 2 metros e peso de oito toneladas cada, que originalmente faziam parte do alto-forno de ferro-gusa. O próprio Peter Latz realça a importância da Piazza Metallica como "símbolo do parque e ao mesmo tempo programa de meu trabalho, a metamorfose de uma estrutura industrial existente em parque público" (2003, p. 109).

Analisando a composição do parque, chama a atenção o plantio em grelha da vegetação arbórea. Latz explica que um plantio à inglesa geraria contraste, o que daria a impressão de que a natureza está reconquistando a área, conceito que não lhe agra-
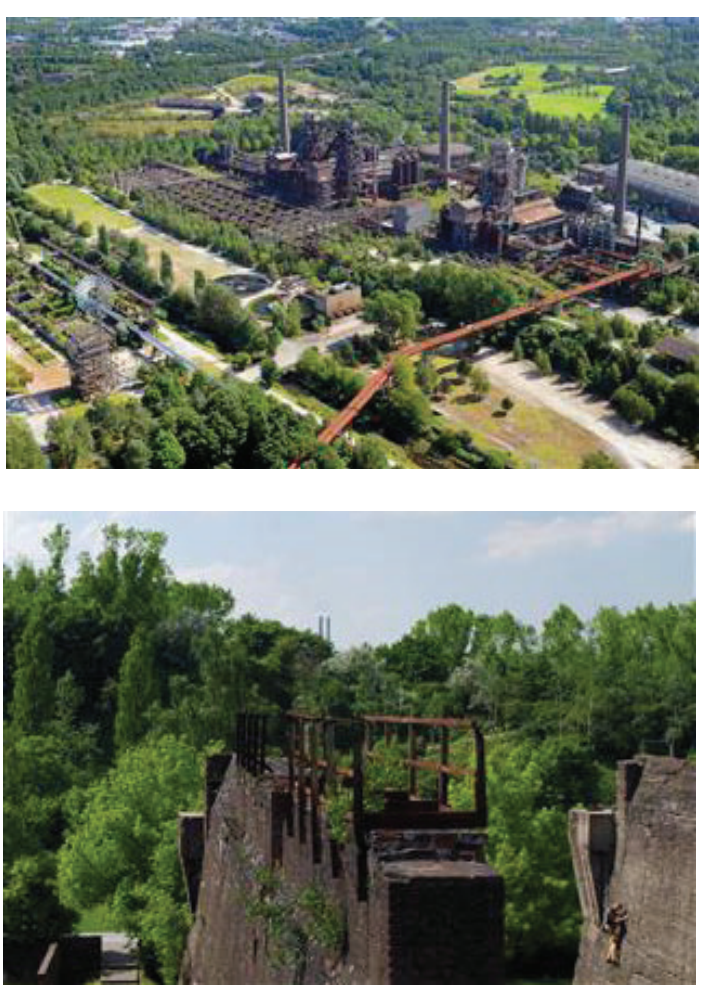
da ideologicamente. Ao invés disso, "se eu plantar as árvores numa grelha ou em fileiras, então eu estou trabalhando com a mesma linguagem da arquitetura industrial e as árvores ainda irão florescer exatamente como fariam em uma composição paisagística livre" (apud WEILECHER, 2008, p. 129). Latz se valeu da vegetação espontânea para lidar com as limitações típicas de uma área caracterizada por solo pobre, alcançado uma diversidade considerável, com mais de 200 espécies registradas (REED, 2008, p. 124).

Figuras 3 e 4: Vista aérea do landschaftspark e detalhe da requalificação de estrutura industrial como parede para escalada. Créditos: (c)Udo Becker e (c) Nathalie Bucholski (inferior). 
O legado industrial do Landschaftspark Duisburg-Nord constava ainda de extensa rede de trilhos e passarelas que foram utilizadas por Latz e equipe para estruturar os eixos de circulação e os acessos a diferentes setores do parque e até mesmo às urbanizações adjacentes. O núcleo desse sistema, onde os caminhos se aproximam, foi batizado de Gleisharfe (ou "The Rail Harp") e é considerada uma das áreas mais interessantes do parque possibilitando uma visão panorâmica do complexo (LATZ, 2003, p. 112).
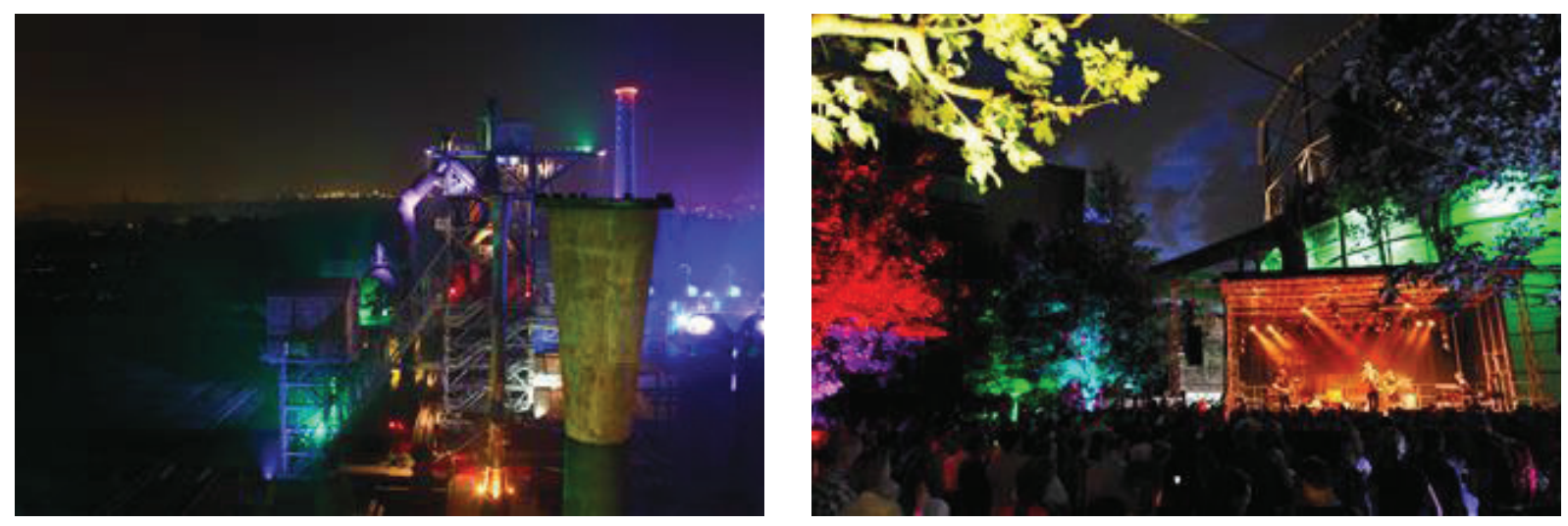

Figuras 5 e 6: Duisburg-Nord à noite. Créditos: (c)MichaelMensche (esq) e (c)Alexander Kranki (dir).

A implantação do parque durou de 1990 a 2002 e foi marcada por uma série de medidas com o objetivo de mitigar ou até mesmo reverter o passivo ambiental da área. Neste sentido vale registrar o programa de bioremediação de solo contaminado, a reciclagem de materiais de demolição como substrato (ou incorporado ao concreto e pavimentos) e o tratamento do escoamento superficial da chuva em leitos de sedimentação vegetados. Vale registrar que algumas dessas medidas sofreram criticas de ambientalistas e de arquitetos que entendiam que o passivo ambiental deveria ser tratado de maneiras mais convencionais.

Do ponto de vista formal, Reed entende que "em Duisburg-Nord, Latz reintroduziu a alegoria e o senso de sublime no paisagismo contemporâneo" (2008, p. 26).

\section{High Line}

O High Line é um parque novaiorquino construído sobre 2,4 km de linha ferroviária desativada nos anos 80 . Este parque linear atravessa 22 quarteirões, quase sempre intraquadra e suspenso a 9 metros do chão, e tornou-se rapidamente um novo cartãopostal da cidade. 
É curioso observar que durante 20 anos o destino do High Line parecia ser a demolição. A linha ferroviária abandonada era acusada de ser um obstáculo físico que fragmentava o tecido urbano, impedindo o desenvolvimento do West Side. Além disso, era símbolo de uma era passada que destoava do charme, modernidade e dinamismo da Manhattan da virada de milênio. No entanto, em 1999, um grupo de moradores novaiorquinos criou o Friends of the High Line, associação que defendia a permanência do antigo leito ferroviário.

Em 2005, tendo convencido o poder público e já operando com o fundo de capital privado criado em 2003, o Friends of the High Line iniciou uma série de discussões públicas acerca da requalificação do elevado em que participaram as firmas de arquitetura e design James Corner Field Operations e Diller Scofidio + RENFRO.

A primeira seção do parque foi inaugurada em 2009 e a segunda em 2011. Há uma terceira em fase em desenvolvimento, prevista para ser inaugurada em 2014.

Umas das primeiras condições colocadas para os projetistas do High Line foi a manutenção da vegetação espontânea que crescia entre os trilhos. De fato, o "mato" já desempenhara um papel importante: entre 2000 e 2001, quando ainda se cogitava demolir a estrutura, o fotógrafo Joel Sternfeld realizou um ensaio em que retratava a peculiaridade desta paisagem composta por plantas que cresciam espontaneamente entre os abandonados trilhos de trem. Retratando-as com a cidade ao fundo, conseguiu sensibilizar parte da população pela manutenção do elevado.
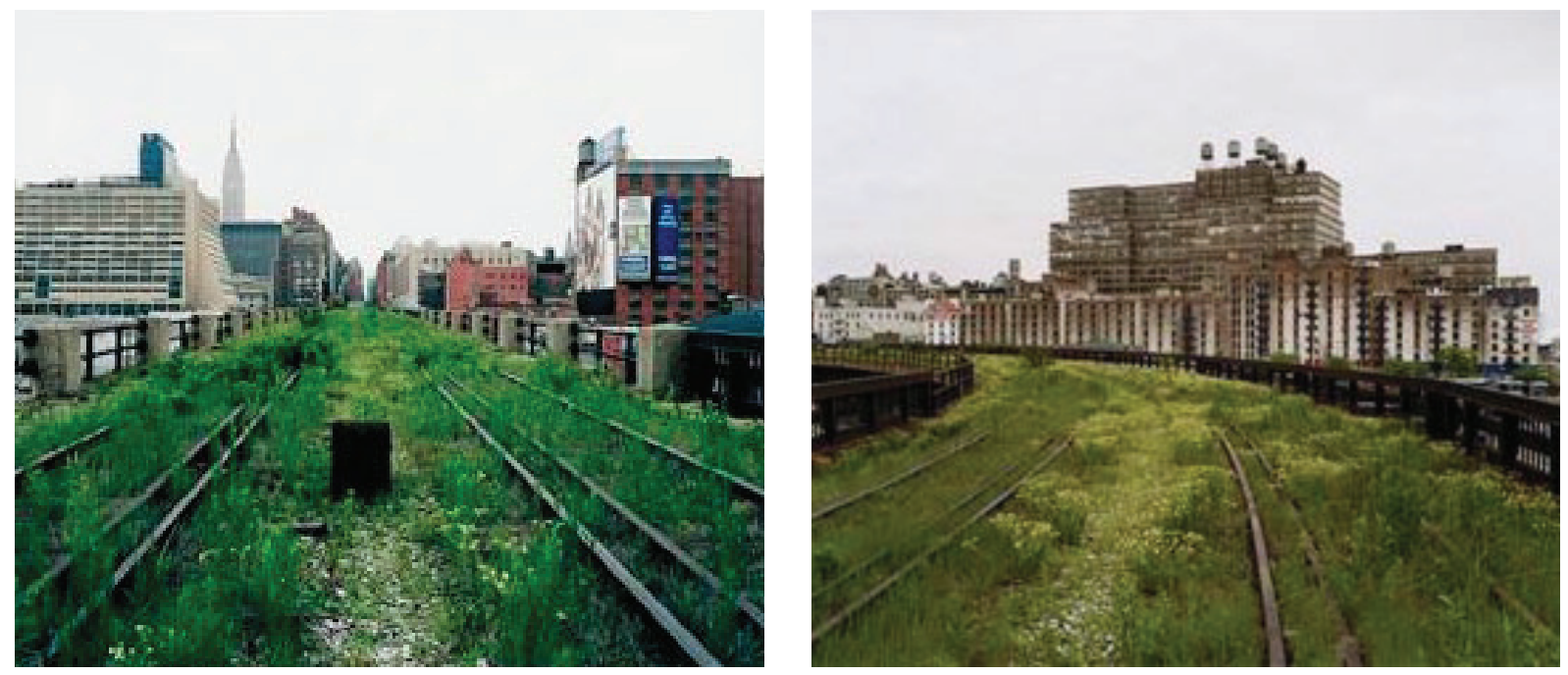

Figuras 7 e 8: Fotos de Joel Sternfeld desempenharam importante papel junto à opinião pública. Crédito: Joel Sternfeld @ 2000. 
Como relata James Corner, o projeto tomou partido dessa paisagem espontânea, obra de sementes transportadas pelo vento, pela chuva, por pássaros e pequenos roedores e pelo próprio trem:

Do ponto de vista estético e de design, sempre foi a nossa posição tentar respeitar o caráter inato do próprio High Line: a sua singularidade e linearidade, seu pragmatismo direto, suas propriedades emergentes com as plantas selvagens prados, bosques, trepadeiras, musgos, flores, misturadas com pedras de lastro, trilhos de aço e concreto (FRIENDS OF THE HIGH LINE, 2011, p. 30).

A solução foi desenvolver um piso de concreto com aberturas longitudinais cônicas que permitissem a entrada de água e a existência de plantas. Corner considera que a vegetação espontânea conferiu um caráter selvagem e dinâmico para o projeto, uma paisagem única que para ser apreciada demanda a diminuição no ritmo das pessoas. Para facilitar isso, optou-se por caminhos meândricos, escadas longas e nichos escondidos com muitos assentos.
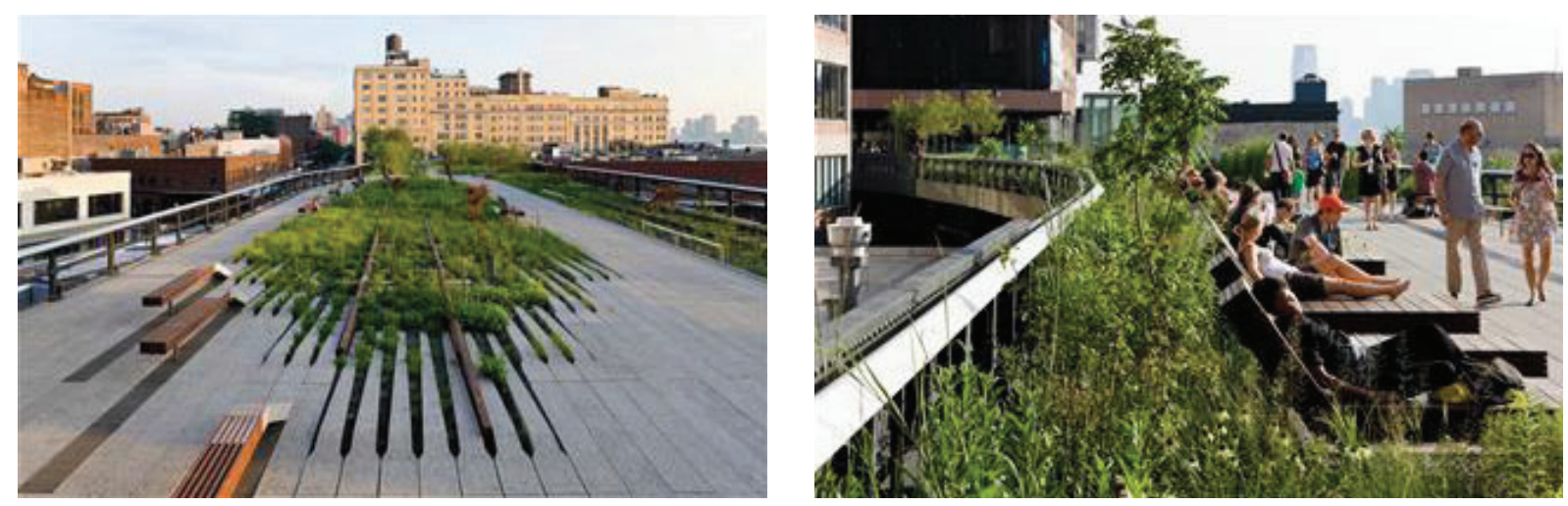

Figuras 9 e 10: Piso especialmente projetado para permitir a existência de vegetação espontânea. Estas colocam um novo ritmo às pessoas. Créditos: Iwan Baan (c) 2009.

Ricardo Scofidio, outro arquiteto envolvido no projeto, chegou a batizar essa fusão entre a vegetação e materiais construídos de agri-tetura (agri-tecture), um jogo com as palavras agricultura e arquitetura.

O legado industrial da área também foi valorizado no projeto. Além da paisagem entre trilhos, especial cuidado foi dispensado às estruturas art deco do elevado. Entre os princípios de design estavam: "preservar trilhos", "preservar e revelar estruturas", "preservar as condições incomuns" e "preservar a presença industrial no nível da rua". 

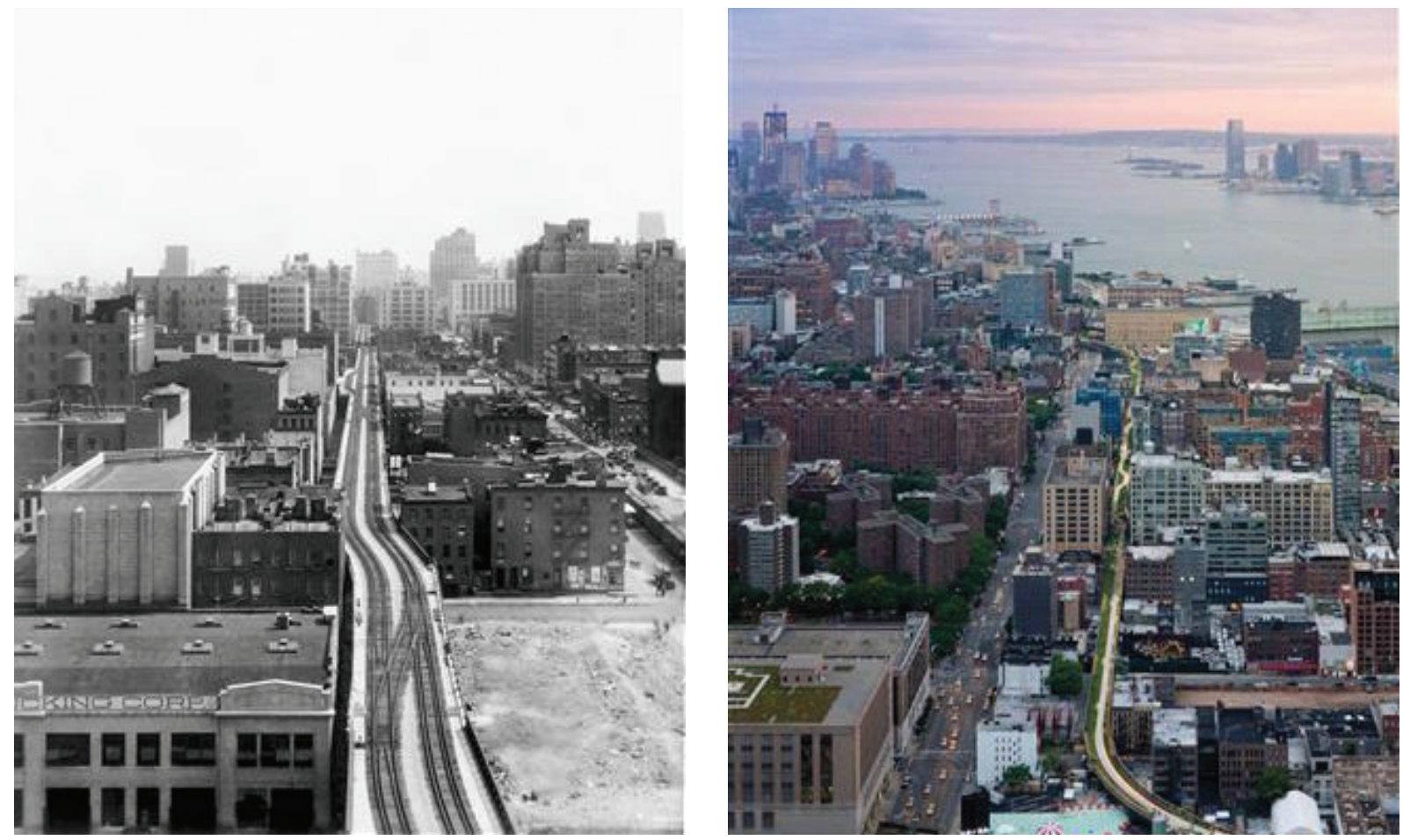

Figuras 11 e 12: High Line em 1934 e em 2011. Créditos: Iwan Baan @ 2011.

Hoje o parque é mantido por uma parceria entre o departamento de parques da cidade de Nova York e o Friends of the High Line, em que este entra com mais de $90 \%$ do capital necessário para a operação do parque. No entanto o High Line está sendo acusado de gentrificar a área e, por apresentar problemas não previstos, suspeita-se que está drenando recursos que seriam dedicados à manutenção de outros parques da cidade.

\section{Parque da Juventude}

Em São Paulo, a paisagista Rosa Kliass manteve parte das ruínas do inacabado Complexo Penitenciário Carandiru II para configurar o setor central do Parque da Juventude 3 .

Este setor, um parque em si mesmo, ocupa $95 \mathrm{mil}^{2}$ dos $240 \mathrm{mil} \mathrm{m}^{2}$ da área total do Parque da Juventude. Ele possui caráter contemplativo, que é em grande parte induzido por uma paisagem inusitada, fruto da transformação de antigas estruturas prisionais em

\footnotetext{
3 "O projeto urbanístico-paisagístico tratou a área segundo três faixas de intervenção dispostas de leste a oeste, que correspondem a três etapas de implantação, das quais as duas primeiras (parque esportivo e parque central) foram inauguradas entre 2003 e 2004 e a terceira em 2006. (KLIASS, 2011, p. 78)
} 
equipamentos e em elementos-chave da composição do parque. Em suas palestras, a autora do projeto se refere a esse setor como "Arqueologia do Contemporâneo".

A antiga muralha de vigilância foi transformada em passarela elevada de observação, o Passeio da Muralha. Esse equipamento permite observar o parque de pontos elevados e oferece ainda a possibilidade incomum do frequentador do parque colocar-se na mesma altura da copa das árvores. O acesso a essas antigas muralhas foi estruturado em aço corten, que por ter o aspecto de ferrugem parece reforçar a presença do caráter "ruína" na composição paisagística.
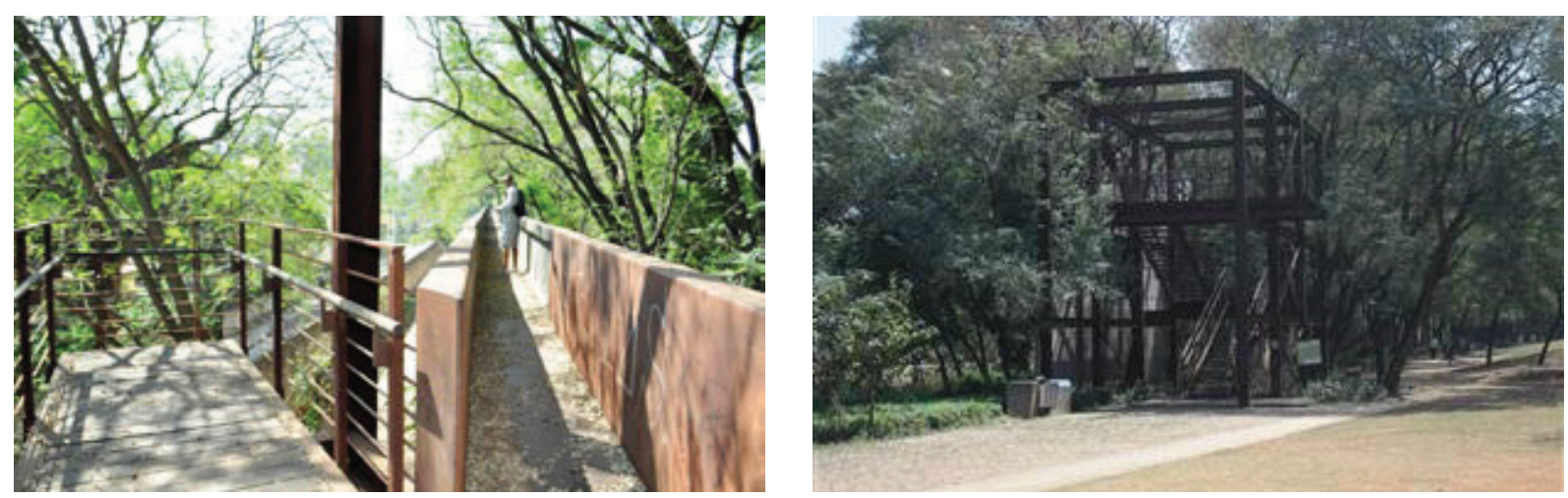

Figuras 13 e 14: O Passeio da Muralha. O seu acesso é feito por estruturas em aço corten. Fotos do autor.

O núcleo do setor são as colunas e vigas em concreto armado com vergalhões aparentes. Tomadas por vegetação rasteira, trepadeiras e tipuanas que cresceram quando a construção da nova ala do presídio foi abandonada em 1993, essas estruturas são agora oferecidas à experimentação do público por meio de um sistema de deques de madeira levemente elevados que permite circular no espaço sem o risco de destruir a vegetação que cresceu na área de maneira espontânea.
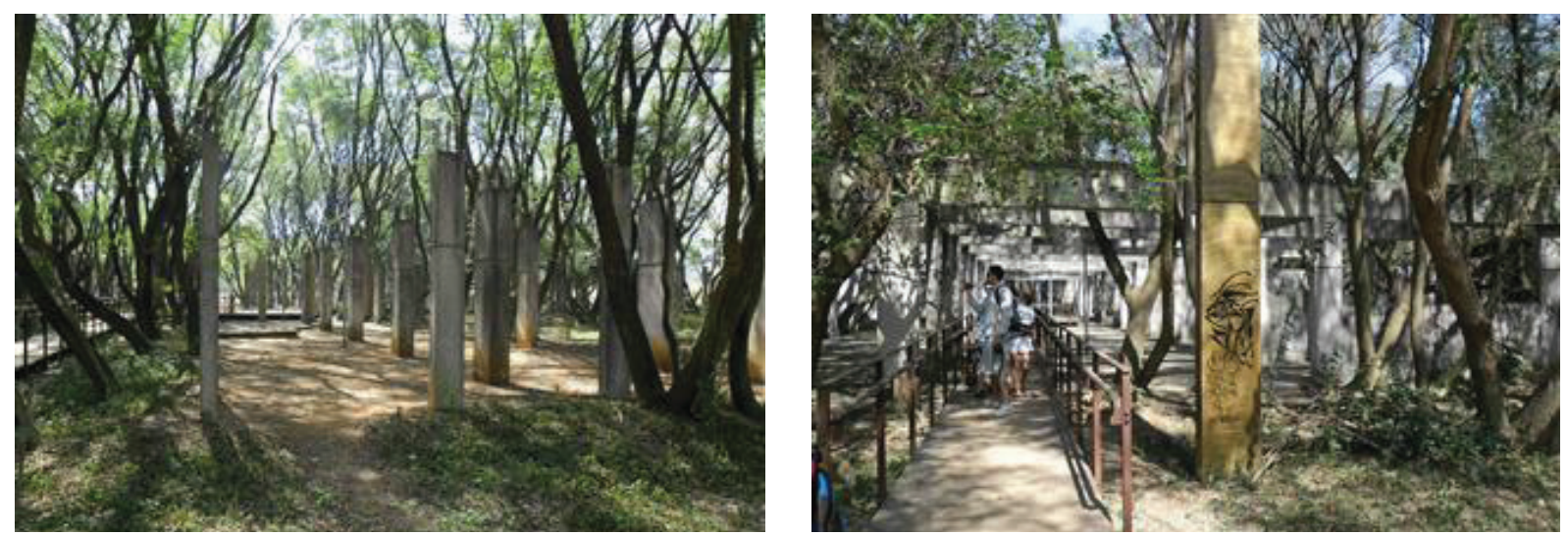

Figuras 15 e 16: A abandonada nova ala do Carandiru Il foi colonizada por vegetação espôntanea. A fim de preservá-la, o acesso a essa área é feito por deques de madeira. Fotos do autor. 


\section{Parque Victor Civita}

Recém-alçada à categoria de parque, a antiga praça Victor Civita foi construída em área que já abrigou o antigo incinerador de resíduos domiciliares e hospitalares do bairro de Pinheiros, que funcionou de 1949 a 1989. O espaço foi viabilizado por um termo de cooperação firmado entre a prefeitura da cidade de São Paulo e o Grupo Abril, em negociação que estendeu de 2001 a 2007. Antes de virar praça em 2008, a área abrigou três cooperativas de reciclagem, o que aumentou os problemas de contaminação do solo já existentes.

Seus 14 mil metros quadrados acolhem um programa focado na educação ambiental e em atividades culturais e esportivas. O parque possui uma série de espaços com a temática das "boas práticas ecológicas": horta orgânica, fitoterápicos, biocombustível, permacultura, reuso de água e compostagem.

O antigo prédio do incinerador foi convertido em Museu da Sustentabilidade. Mas antes de ser ocupado teve que passar por um processo de descontaminação que envolveu a raspagem de seu interior para remoção da camada contaminada por dioxinas e furanos (SVMA, 2010, p.81). Hoje o Museu da Sustentabilidade abriga uma exposição permanente que conta a história do lugar e o destino do lixo em São Paulo.
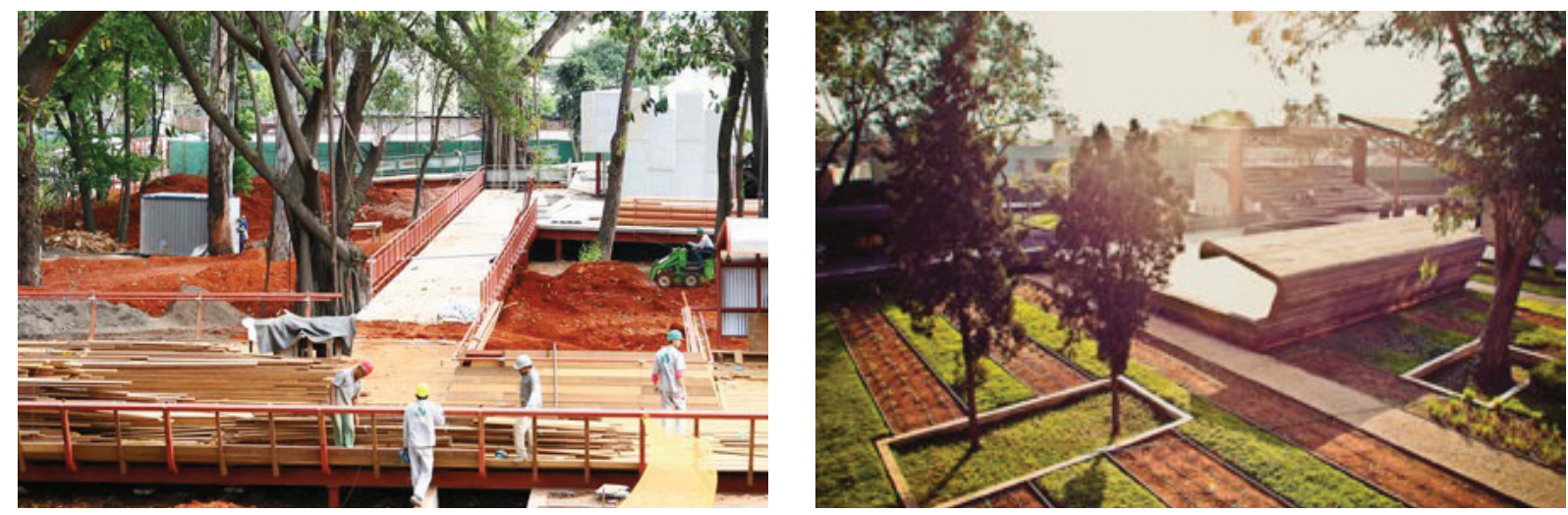

Figuras 17 e 18: Decks elevados evitam contato com o solo contaminado. Créditos: www.praçavictorcivita.org.

Se por um lado o projeto do Parque Victor Civita foi feliz ao tomar partido da degradação do local para propor um programa focado na temática ambiental por outro lado a maneira como lidou com a degradação do espaço é bastante conservadora. Ao invés de experimentar métodos ecológicos de que já vem sendo usados no exterior há algum tempo, como a fitoremedição, a solução de projeto foi a contenção do solo nos pontos mais contaminados e o acréscimo de uma camada de solo de $50 \mathrm{~cm}$ para 
receber o plantio ${ }^{4}$. Ainda contaminado, o contato das pessoas com o solo é evitado por meio de decks elevados que se estendem por toda a praça.

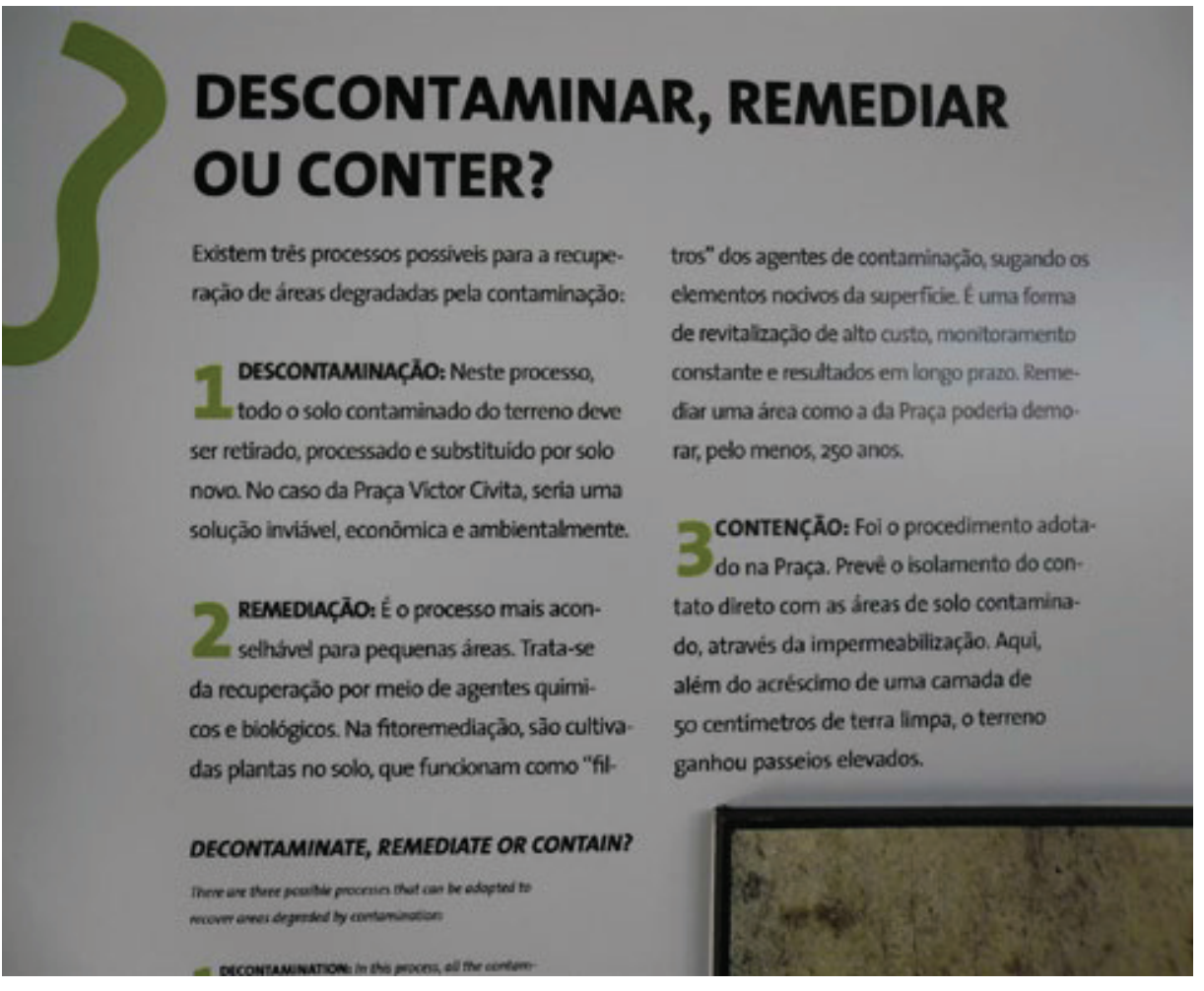

Figura 19: Cartaz no Museu da Sustentabilidade, no Parque Victor Civita evidencia a diferença entre o discurso e a prática. Foto do autor.

O parque tem sido apontado como uma referência em vários aspectos: capta a água de chuva para reuso, sua iluminação é feita por led, investe na geração de energia alternativa, a água dos banheiros é tratada por um wetland que fica em frente ao antigo prédio do incinerador para a irrigação do bosque.

O espaço é gerido pela Associação Amigos da Praça Victor Civita, cujo modelo de gestão envolve empresas, instituições públicas, ONGs e a comunidade.

Tendo em vista que a propriedade do terreno é da prefeitura, com concessão de uso para o Grupo Abril - o que significa que o parque poderá ser gerido pela municipalidade no futuro - questiona-se aqui a pertinência do emprego de soluções e elementos cuja manutenção depende de aporte técnico e financeiro que parecem estar, no momento, muito além da capacidade de gestão da municipalidade.

\footnotetext{
${ }^{4}$ A arquiteta Anna Julia Dietzsch, autora da Victor Civita ao lado de Adriana Blay Levisky, declarou ao site Arquitextos que gostaria de ter usado a fitoremediação, mas que problemas legais e de custo inviabilizaram a ideia. Disponível em <http://www.vitruvius.com.br/revistas/read/projetos/11.126/3946>. Acessado em 18 de junho de 2013.
} 
Além disso, seu programa ignora por completo a histórica concentração de trabalhadores do bairro de Pinheiros, optando por atividades (e estética) que dialogam apenas com uma pequeníssima parte da população ${ }^{5}$. Por conta disso, o praça/parque parece menos uma área pública 'para todos' e mais uma manifestação espacial da ideologia do Grupo Abril em esperta ação de marketing verde.
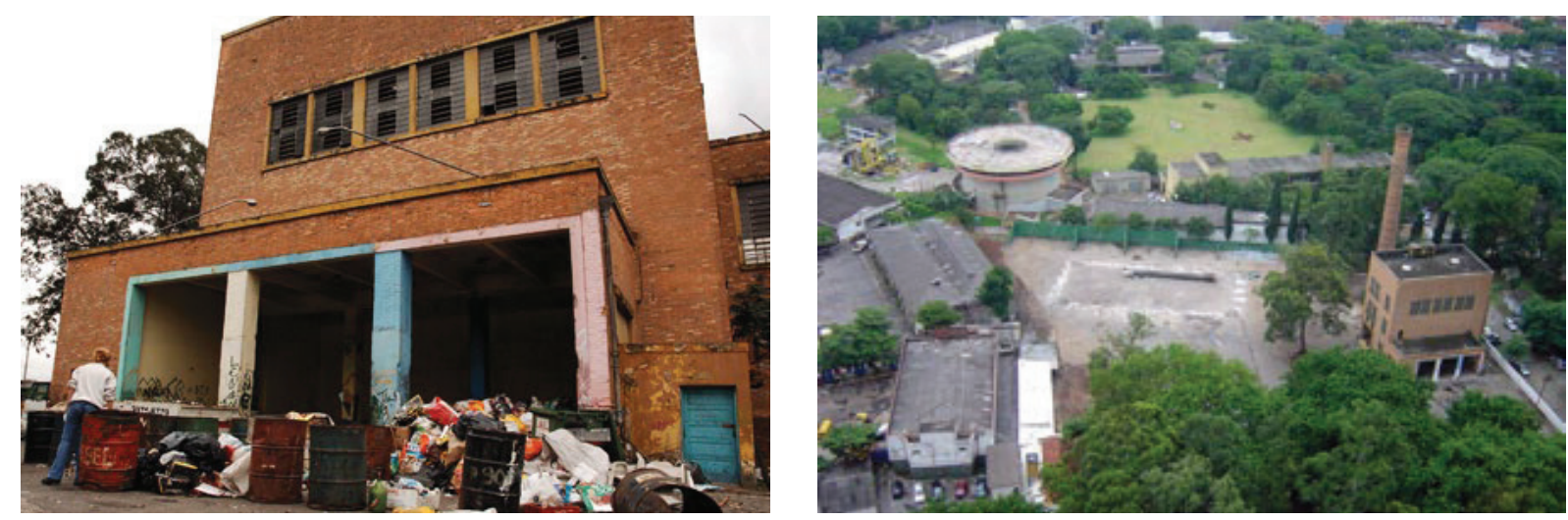

Figura 20 e 21: Antes de ser praça, a área estava abandonada e era usada por cooperativas de reciclagem. Imagem: www.pracavictorcivita.org. À direita, vista aérea do incinerador. Foto: Ricardo Vendramel/SECOM.

\section{Gas Works Park}

Segundo Reed (2005), o Gas Works Park de Seattle (Washington) pode ser considerado um precedente na adaptação de áreas abandonadas para novos usos. O parque foi inaugurado em 1975 e ocupa o terreno de 10 hectares que pertenceram a uma usina de gás fechada em 1956

As estruturas industriais iriam ser removidas, mas Richard Haag, arquiteto paisagista responsável pelo projeto, ao perceber que poderia tratá-las como elementos de arte abstrata, decidiu mantê-las:

Comecei com o lugar. Eu frequentava os edifícios e deixava o espírito do lugar me dominar . Eu comecei a ver o que eu gostava e então eu gostei do que vi - novos olhos para velho. Manchas de óleo permanente tornaram-se planícies

\footnotetext{
${ }^{5}$ Segundo avaliação de uso e ocupação realizada por Brígido e Hirao (2011) "percebe-se a utilização do lugar por um público instruído, cujo interesse é proporcionado pelo seu conteúdo didático, e também por sua localização, em área nobre rodeada por grandes empresas, uma vez que $50 \%$ dos usuários reside ou trabalha no bairro de Pinheiros" (p. 18).
} 
com afloramentos de concreto, refugos industriais eram colinas, as torres eram florestas de ferro e sua presença taciturna tornou-se o mais sagrado dos símbolos. Eu aceito estes presentes, e decidi absolver sentimento vingativo da comunidade para a usina de gás. As espécies ameaçadas da revolução industrial foram salvas da extinção através do uso adaptativo (idem, p. 25).

A opção não foi aceita prontamente. A ideia gerou descontentamentos entre a população e políticos, que à época não atribuíam valor algum a essas estruturas oxidadas pelo tempo, bem ao contrário. Hoje, no entanto, a decisão se mostrou acertada: a 'fábrica' é um dos e destaques da paisagem da região, um marco visual da bacia do lago Union. Muitas das antigas estruturas foram coloridas e adaptadas para serem usadas como brinquedos.
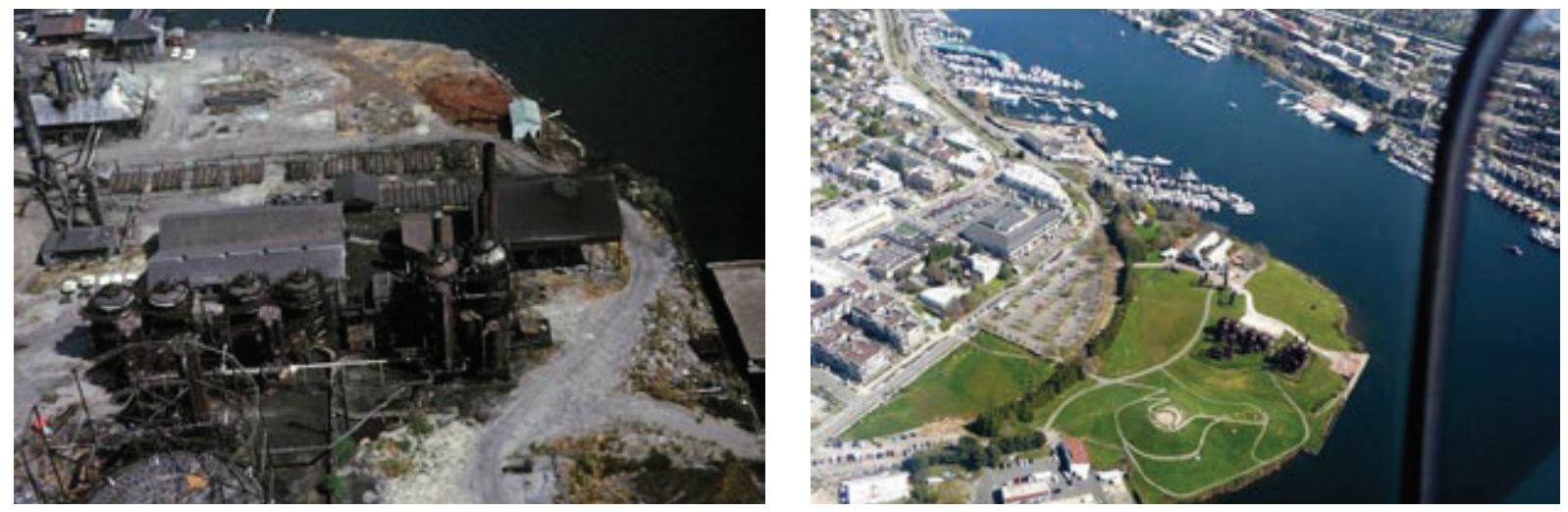

Figuras 22 e 23: Antes e depois. Créditos: City of Seattle e Friends of Gas Works Park.
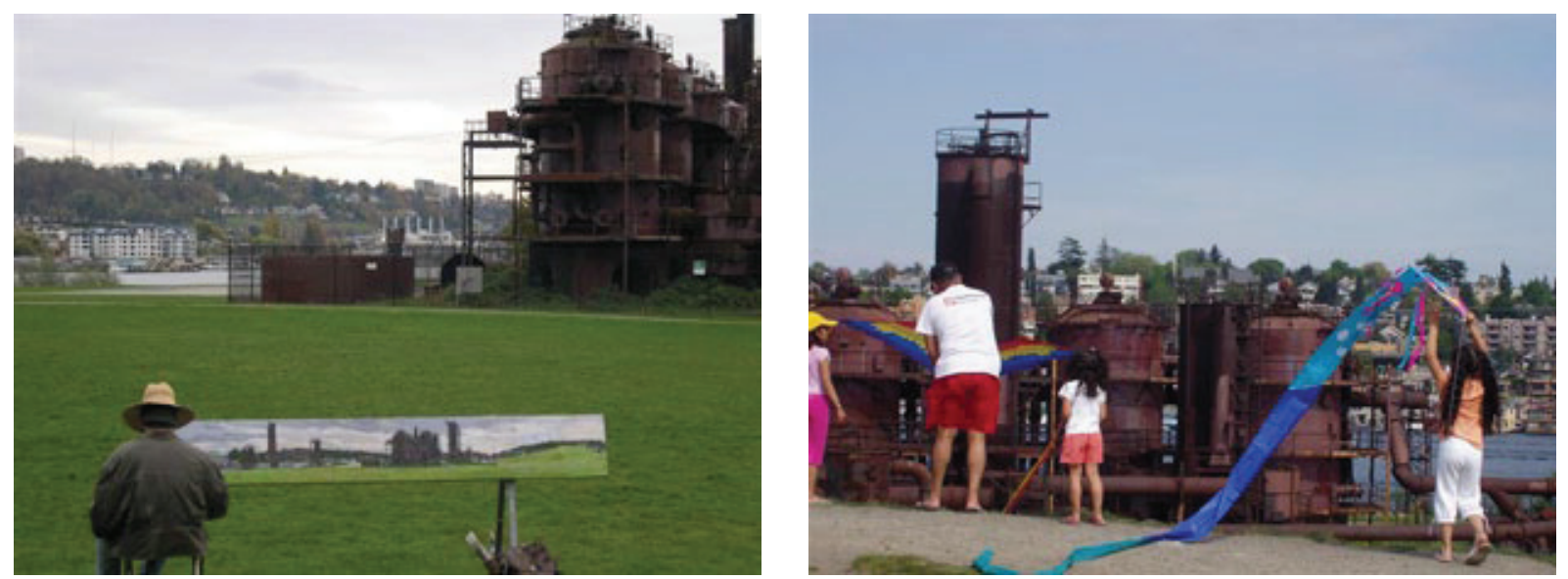

Figuras 24 e 25: Da rejeição à apropriação. Créditos: Richard Haag, 2007.

Haag lançou mão de práticas ecológicas avançadas para a época. Como relata Cerver (1995), ao invés de descartar o solo contaminado por hidrocarbonetos, utilizou um processo de bioremediação que revelou ser uma opção muito mais econômica do que a convencional. 

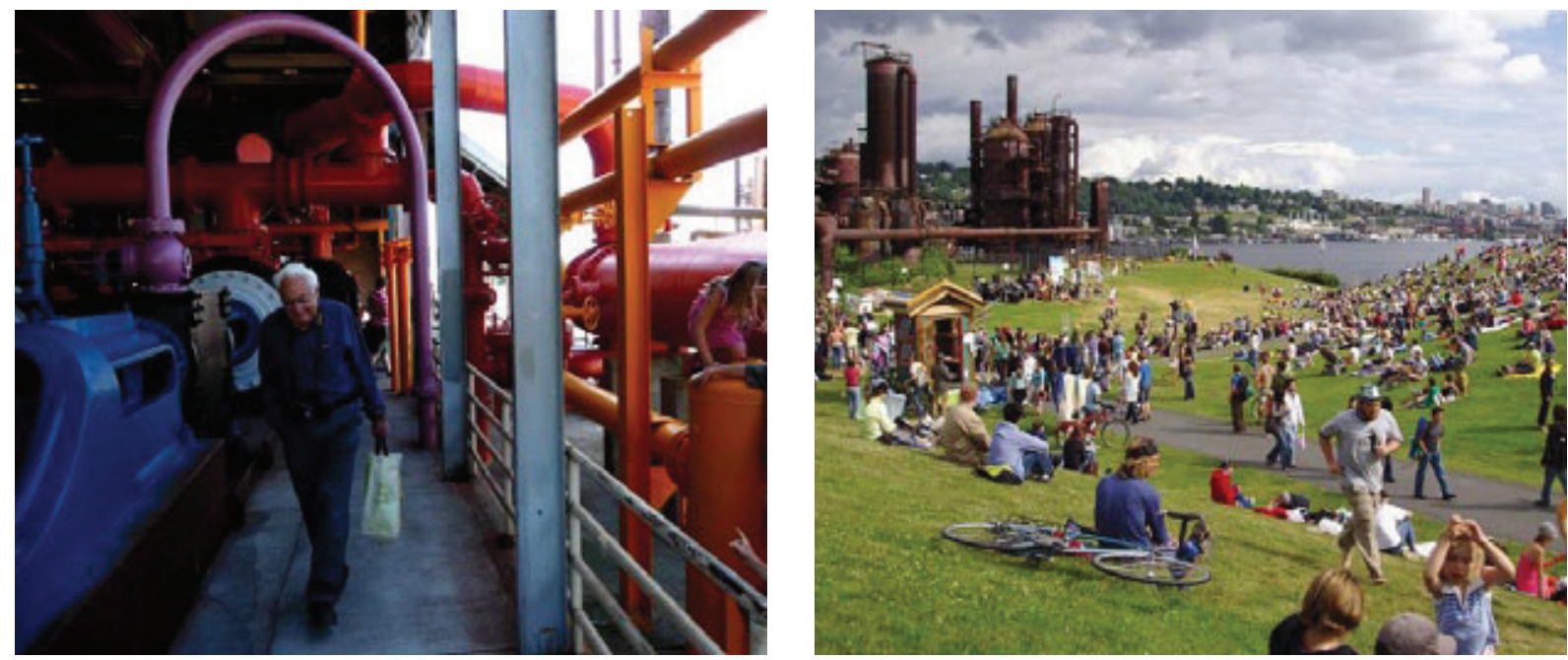

Figuras 26 e 27: Haag visita sua obra (e crianças se divertem nas estruturas industriais coloridas). Crédito: Patrick Waddell, 2011. À direita, multidão no solstício de verão. Crédito: Richard Haag, 2007.

Em janeiro de 2013, o Gas Works Park entrou na lista de lugares históricos da National Register of Historic Places, e agora recebe incentivos fiscais para a sua preservação. E é um dos parques mais utilizados de Seattle, reunindo até 300 mil pessoas em datas comemorativas.

\section{DO ABANDONO, ALGUMAS PERCEPÇÕES}

A análise crítica dos estudos de caso apresentados (selecionados por serem considerados referencias na área da arquitetura da paisagem), embasada no referencial teórico do Landscape Urbanism e no conceito de Terceira Paisagem, convida a um esforço de síntese no sentido de se verificar se os projetos de paisagem de áreas abandonadas que não negam a história do lugar possuem características comuns que os diferenciam das demais intervenções paisagísticas.

Não pretende-se, no entanto, provar a existência de um novo "tipo" de parque ou momento na história do paisagismo, o que, embora não possa ser descartado, demandaria mais espaço e munição do que a que dispomos no momento. Almeja-se isso sim, colocar hipóteses que possam instigar mais estudos. E trazer questões para serem apreciadas por todos aqueles que intervêm e vivem a paisagem.

Posto isso, em nossa opinião, de um ponto de vista estético, a paisagem decorrente da requalificação de áreas abandonadas, ao menos até o momento, parece 
evocar sensações mais alinhadas à ideia de sublime ${ }^{6}$ do que as de belo ou de pitoresco na paisagem.

Embora certamente não se aplique somente aos casos de projetos de paisagem em áreas abandonadas, vale registrar a importância do envolvimento da população na constituição de novos espaços públicos. Paradoxalmente, detecta-se resistência de parte desta quanto a projetos não convencionais - sobretudo de setores sob influência do discurso ambientalista.

No Brasil é extremamente arriscada a incorporação de novas técnicas ecológicas de remediação de áreas industriais contaminadas. Uma legislação ambiental restritiva e pouco flexível e um processo de licenciamento ambiental demorado e pouco transparente podem simplesmente inviabilizar um projeto estruturado em novas tecnologias ecológicas.

Na prática, observa-se um ambiente legal que não incentiva a inovação no projeto de paisagem e que condiciona a sua aprovação ao contexto político, à troca de favores, elementos tão característicos da sociedade brasileira.

Mais do que exemplos de diálogo entre paisagem e edificação, alguns dos projetos aqui analisados parecem apontar na direção da fusão entre ambos, com edificações desempenhando funções tipicamente confiadas aos espaços livres tais como circulação, lazer ao ar livre e receptáculo de vegetação.

Em contrapartida, a paisagem desses projetos desempenham funções muito diferentes das comumente esperadas das áreas verdes: remediação de áreas contaminadas, purificação de águas poluídas, preservação de patrimônio histórico e configuração de marcos visuais de grande impacto. São paisagens que desempenham funções infraestruturais e sociais comumente confiadas à arquitetura e à engenharia.

Outra inovação que emerge com o projeto de paisagem de áreas abandonadas é a atribuição de valor paisagístico à vegetação ruderal ${ }^{7}$, o que rompe com a tradição dominante que considera tais espécies simples ervas daninhas a serem suprimidas da paisagem.

\footnotetext{
6 "Tudo que seja de algum modo capaz de incitar as idéias de dor e de perigo, isto é, tudo que seja de alguma maneira terrível ou relacionado a objetos terríveis ou atua de um modo análogo ao terror constitui uma fonte do sublime, isto é, produz a mais forte emoção que o espírito é capaz. (BURKE, 1993, pg 48)

7 Dá se o nome de vegetação ruderal àquelas espécies e comunidades vegetais que se desenvolvem em ambientes fortemente perturbados pela ação humana.
} 


\section{PARA O ABANDONO, ALGUMAS CONSIDERAÇÕES}

As áreas urbanas abandonadas necessitam de políticas públicas capazes de evitar a sua ocorrência, mensurar o seu impacto socioambiental e fomentar o seu redesenvolvimento com vistas à obtenção dos benefícios sociais, econômicos, ambientais que essas áreas são capazes de proporcionar.

A transformação de estruturas abandonadas em nova dimensão do projeto de paisagem demanda abordagens sensíveis e criativas, em que as intervenções conciliem os novos usos do espaço com o respeito à paisagem pré-existente. Neste sentido, um primeiro passo pode ser o repúdio à prática modernista ainda bastante comum de se transformar a área sob intervenção em "tábula rasa", como se o espaço não fosse nada além de folha em branco a ser preenchida pela genialidade do artista.

A complexidade das áreas abandonadas - em que se destacam os passivos ambientais - colocam novas questões àqueles que intervêm na paisagem e sugerem que o seu enfrentamento só é possível por esquipes multidisciplinares, sem prejuízo à necessidade de que o fenômeno da desindustrialização seja mais bem abordado na academia.

E por fim, parecem ser nas tensões - entre problema e oportunidade, entre passivo ambiental e patrimônio histórico, entre edificação e paisagem, entre conservação e renovação e entre a tradição dos parques como escape do urbano e o sucesso de novos parques cujo partido destaca um legado urbano ${ }^{8}$ - que reside o caráter peculiar, único e extraordinário das paisagens abandonadas.

\footnotetext{
${ }^{8}$ Não deixa de ser irônica a presença de elementos industrias nas áreas verdes. Afinal, como explica Harvey (1982) a dicotomia cidade/natureza foi imposta pelo capitalismo industrial do sistema fabril, que estabeleceu a divisão artificial entre o local de viver e o local de trabalhar. Com esta ruptura, a natureza deixou de ser vista como o substrato que garante a sobrevivência para reduzir-se à noção de "tempo livre", algo a ser "consumido" durante as pausas das relações degradantes com a natureza no ambiente de trabalho.
} 


\section{REFERÊNCIAS}

BRÍGIDO, N. M; HIRAO, H. A praça Victor Civita e o Desenvolvimento Sustentável: uma avaliação do uso, apropriação e imaginário. Disponível em: http://revista.fct. unesp.br/index.php/topos/article/view/2281/2086. Acessado em 18 de junho de 2013.

BURKE, Edmund. Uma investigação filosófica sobre a origem de nossas idéias do sublime e do belo. Campinas: Papirus, 1993. Revista Tópos Vol.5, No 2. Unesp, 2011.

CERVER, Francisco Asensio. World of environmental design - civil engineering (nature conservation and land reclamation. Barcelona: Arco Editorial, 1995.

CLÉMENT, Gilles. Manifiesto del Tercer Paisaje. Barcelona: Gustavo Gili, 2007.

Guidelines for the planetary Garden. In: ROCCA, Alessandro. Planetary Gardens - The Landscape Architecture of Gilles Clément. Basel: Birkhauser, 2008.

CORNER, James. Terra Fluxus. In: WALDHEIM, Charles. The Landscape Urbanism Reader. New York: Princeton Architectural Press, 2006.

FRIENDS OF THE HIGH LINE. Design the High Line - Gansevoort Street to $30^{\text {th }}$ Street. New York: Friends of the High Line, 2011.

HARVEY, David. "O Trabalho, o capital e o conflito de classes em torno do ambiente construído nas sociedades capitalistas avançadas". Espaço \& Debates n.6, 1982.

HUNG, Ying-Yu. Landscape Infrastructure: Systems of Contingency, flexibility, and adaptability. In: HUNG, Y; AQUINO,G. Landscape Infrastructure: Case Studie by SWA. Basel: Birkhauser, 2011.

KLIASS, Rosa. Desenhando paisagens, moldando uma profissão. São Paulo: Editora Senac, 2011.

LATZ, Peter. Extraordinary landscapes following the era of the industry. In: Paisagem Ambiente, n.17. São Paulo: FAU-USP, 2003. 
LOMBARDO, Magda Adelaide; VOLPE, L.L; VASQUES, A.R. A Importância da Análise dos Riscos de Contaminação na Reabilitação de Brownfields Urbanos. In: II Congresso Internacional de Riscos, 2010, Coimbra. Afirmar as Ciências Cindínicas: Reequacionar o Conhecimento dos Riscos e das Catástrofes. Coimbra : Nicif, 2010. v. 1. p. 1-12.

MCKEEHAN, P. Brownfields: The Financial, Legislative and Social Aspects of the Redevelopment of Contaminated Commercial and Industrial Properties. Cambridge Scientific Abstracts, 2000. Disponível em <http://www.csa.com/discoveryguides/brown/ overview.php>. Acessado em 13 de setembro de 2012.

REED, Peter. Groundswell: Constructing the Contemporary Landscape. New York: Museum of Modern Art, 2008.

SÒLA-MORALES, Ignasi de. Terrain vague. In: ÁBALOS, Iñaki. Naturaleza y artifício - el ideal pintoresco em la arquitectura y el paisajismo contemporáneos. Barcelona: Gustavo Gili, 2009.

SPIRN, Anne W. O Jardim de Granito. São Paulo: Edusp, 1995.

SVMA. Relatório da Qualidade do Meio Ambiente. São Paulo: PMSP/SVMA, 2010.

VASQUES, Amanda Ramalho. Considerações sobre estudos de caso de brownfields: Exemplos no Brasil e no Mundo. Biblio 3w (Barcelona), Barcelona, v. Vol. X, n.n 648, p. 1-13, 2006. Disponível em <http://www.ub.edu/geocrit/b3w-648.htm>. Acessado em 04 de junho de 2013.

WALDHEIM, Charles. Landscape as Urbanism. In: The Landscape Urbanism

Reader. New York: Princeton Architectural Press, 2006.

WEILACHER, Udo. The Syntax of Landscape - The Landscape Architecture of Peter Latz and Partners. Basel - Berlin - Boston: Birkhauser Publisher, 2008. 